Article

\title{
A century of ethnic changes in the Romanian territories united with the Kingdom of Romania in 1918
}

\author{
Ionel Muntele ${ }^{1,2 \otimes}$, Costel-Cosmin Sîrbu ${ }^{1}$, Raluca-Ioana Horea-Şerban ${ }^{1}$, \\ Dorin Lozovanu ${ }^{3}$
}

\author{
${ }^{1}$ Alexandru Ioan Cuza University of Iași, Department of Geography, Romania \\ ${ }^{2}$ Romanian Academy, Geography Group, Iași , Romania. \\ ${ }^{3}$ Institute of Ecology and Geography of Academy of Sciences of the Republic of Moldova; National Museum of \\ Ethnography and Natural History from the Republic of Moldova
}

\begin{abstract}
The objective of the study is to clarify to what extent the alienation of a territory and the dynamics of the urbanization process may affect the evolution of the ethnic structure of the population within the timespan of a century. The year 1918 was an essential moment in the territorial evolution of the Romanian state which, in a short time, passed from the imminence of the total occupation by the Central Powers to the resolutions of the 1919-1920 peace treaties that sanctioned the unification of all the regions inhabited predominantly by Romanians. The evolution of the ethnic structure of the population in these territories recorded different tendencies, depending on the political and historical context. The territories that continued to belong to the Romanian state experienced a continuous strengthening of the majority ethnic component, including in urban centres. However, in the territories occupied by the Soviet Union, the territorial fragmentation, the assertion of an artificial national identity (the Moldovan one) and the favouring of Eastern Slavic communities produced complex effects, from marginalization and isolation in rural communities (the case of the territories assigned to Ukraine) to an identity crisis in the Republic of Moldova. The post-communist period registered the same trends in the territories of north-western Romania while being significantly disturbed in the ex-Soviet territories. The results of the study prove the importance of integrating predominantly Romanian territories into the unitary Romanian state.
\end{abstract}

Keywords: ethnic changes, spatial identity, ethnic diversity, ethnic favoritism, spatiotemporal dynamics.

Résumé. La présente étude envisage à clarifier dans quelle mesure l'aliénation d'un territoire ainsi que la dynamique du processus d'urbanisation peut affecter l'évolution de la structure ethnique de la population, pendant un siècle. L'année 1918 a été un moment clé dans l'évolution territoriale de l'état roumain, qui a connu un passage rapide de l'imminence de

\section{CORRESPONDENCE:}

20A Carol I Boulevard, Iasi, 700505 Romania.

@@imuntele@yahoo.fr (I. M.), ralusel@yahoo.com (R.-I.H.-S..), dorinlozovanu@yahoo.com (D.L.)
ARTICLE HISTORY :

Received : 11 May 2019

Received in final form : 15 October 2019

Accepted : 17 October 2019 


\begin{abstract}
l'occupation totale par les Pouvoirs Centraux aux résolutions des traités de paix de 1919-1920 qui ont sanctionné l'unification de toutes les régions habitées par des roumains. L'évolution de la structure ethnique de la population a suivi différentes tendances, selon le contexte politique et historique. Les territoires qui appartenaient toujours à l'État Roumain ont subi un renforcement continu de la composante ethnique majoritaire, y compris dans les centres urbains. Pourtant, dans les territoires occupés par l'Union Soviétique, la fragmentation territoriale, la création d'une identité nationale artificielle (l'identité Moldave) et la favorisation des communautés slaves de l'Est ont entrainé des effets complexes, qui varient de la marginalisation et isolation dans les communautés rurales (le cas des territoires annexés à l'Ukraine) à une crise identitaire dans la République de Moldavie. La période post-communiste a gardé les mêmes tendances dans les territoires du Nord-Ouest de la Roumanie, mais a perturbé de manière significative les territoires ex-soviétiques. Les résultats de l'étude montrent l'importance de l'intégration des territoires à prédominance roumaine dans l'État Roumain unitaire.
\end{abstract}

Mots-clés: changements ethniques, identité spatiale, diversité ethnique, favoritisme ethnique, dynamique spatio-temporelle.

\title{
1. Introduction
}

The year 1918 was an essential moment in the territorial evolution of the Romanian state which, in a short time, passed from the imminence of the total occupation by the Central Powers to the resolutions of the 1919-1920 peace treaties that sanctified the unification of all the regions predominantly inhabited by Romanians in one and the same country. 100 years after these events, an analysis of the changes recorded within the ethnic structure of the territories that formed the Kingdom of Romania after the First World War is imperiously necessary considering their main characteristic: diversity. This diversity has undergone some reshuffle following the retracing of borders and it is a result of successive historical processes. The increase of the demotic exchanges between these territories and the Old Kingdom, possible to a limited extent even before 1918, led in time to the reduction of this diversity, at least in the territories that continued to belong to the Romanian state even after 1947.

The topic of the specific features of the ethnic structure in the territories that were integrated in 1918 in modern Romania has been widely debated so far. The present comparative study is intended to investigate the differences that have occurred in the dynamics of the ethnic structure between the territories that continued to be part of the Romanian state after the Second World War and those that were occupied by U.S.S.R. in 1940-1947, now forming the independent states of Ukraine and the Republic of Moldova. The analysis does not take into account the southern part of Dobrudja, Cadrilater, integrated into the Romanian state in 1913 but retroceded to Bulgaria in 1940, due to the specificity of this territory, which generally falls within the specific evolution of the neighbouring country south of the Danube.

The main hypothesis is based on the idea that the alienation of a territory, even under the conditions of an ethnic majority, is likely to distort the evolution of the ethnic structure, especially under the circumstances of the expansion of the urban 
phenomenon (relatively recent within the Romanian space) and in the authoritarian political context specific to totalitarian regimes. In this context, the preferential migration of minority groups also plays a significant role (Gödri, 2004).

The second hypothesis is supported by the notion of "ethnic favouritism" that would be typical of states built on the nation-state ideology, in which territorial development policies can benefit the dominant ethnic group (Burgess et al, 2011). Other authors consider this notion as a "political axiom" inherent to any territorial construction (De Luca et al, 2018). This favouritism can lead to "ethnic cleansing", a phenomenon that can take on various forms, from brutal to the most subtle ones (Thum, 2007). In this situation, it can be brought forward, locally and episodically, in the case of the territories occupied by U.S.S.R.

In order to support these assumptions, it is necessary to clarify the notion of ethnic group. Its definition is extremely controversial. Jones (2018) speaks of a close link between ethnicity and kinship involving not only genetic (and therefore kinship) exchange but also "ethnic interests" or "ethnic nepotism" generated by the sociopolitical context. Ethnic groups are not, in this conception, immutable, opaque structures, rather assuming a certain porosity, even in the context of some strong cultural or linguistic differences. However, the theory of kinship is not enough to explain the evolution of ethnic identity, there also existing more complex elements such as legislation, norms, political ideals etc. They interfere with large-scale population processes, causing profound transformations that relate to the ethnogenesis process itself.

Ethnic identity is most often linked to spatial identity. The latter rests on central places, landmarks that provide the reason for the existence of the territory (Wackermann, 2008, p. 49). These identities derive either from being rooted in an ancestral territory or from migration. Any active identity corresponds to a steady development of the relationship between society and territory. When this symbiosis, in perpetual becoming, diminishes or disappears, identity loses its meaning. One of the most objective visions of ethnic identity belongs to Frederick Barth (quoted by Blanton, 2015). Its constructivist, social and cultural theory first identifies the conditions that lead to the forms of ethnic construction. Local-level self-organizing strategies play an extremely important role: providing mutual defence, maintaining control over resources, especially when the political environment is chaotic, particularly in refugee areas. Ethnicity is thus a productive way of intensifying cooperation in the challenging context of exchanges and, above all, in the context of the fragility of the political factor that should ensure social cohesion. In some situations, the population in the heterogenous areas is indifferent to the nationalist ideas expressed by elites, preferring peaceful cohabitation (Brubaker et al, 2008). In the same way, there are important differences in the economic and social standard between the dominant groups and the peripheral groups. On the contrary, when 
collective action intervenes in the construction of the state it leads to a consensus which causes the population to mix, the ethnic origin losing its importance, thus bringing about the heterogeneity of the ethnic structure. Conceptually, ethnic diversity is correlated either positively or negatively with poverty and economic development (Churchill, Smith, 2017). The negative nature is due to ethnic and linguistic gaps. Only inter-ethnic cooperation can prevent underdevelopment.

\section{Materials and methods}

In order to analyse the dynamics of the ethnic structure in the territories covered by this study, only official information provided by the censuses carried out over the past 100 years were used. For reasons of continuity and in order to grasp the extent to which the year 1918 was a turning point, information from the previous period was also used, going back to the first modern records (1850 in the territories under the Habsburg Empire and 1827 in the ones under Russian rule). In this way, the analysis extends over two centuries. The information was adjusted according to the present administrative structure of Romania (NUTS 3, counties) or to the one that existed in the interwar period in Soviet territories occupied in 1940, for reasons of comparability. Their aggregation was carried out by separating the urban and rural population, the purpose being that of analysing the dynamics of the ethnic structure by residence, considering the more cosmopolitan character of urban centres. In the case of the urban area, only important cities (exceeding 30,000 inhabitants at present or over the past decades) were taken into consideration, smaller urban centres being more similar to the neighbouring rural environment.

Thus, a database made up of 14 chronological series (11 for Bessarabia, where there is missing data for the period before 1918) was set up, considering only the information on the main ethnic groups: Romanians, Hungarians and Germans for Transylvania; Romanians, Ukrainians, Germans and Jews for Bukovina; Romanians, Ukrainians, Russians, Bulgarians, Gagauzs and Jews for Bessarabia (Table 1).

The derived database, comprising the share of the main ethnic groups during the period mentioned above, was subsequently processed by applying hierarchical ascending classifications (AHC), separately for the two residence environments. For objective reasons, given the division of Bessarabia and Bukovina after 1940, the latter was integrated to the Carpathian territories. In this way, a typology of the evolution of the ethnic structure resulted, synthesizing the main tendencies and their spatial manifestation. The results were comparatively interpreted, using key criteria such as membership / non-membership to the current Romanian state, membership / nonmembership to the Republic of Moldova, or urban hierarchy. 
Table 1. Sources used to build the statistical database

\begin{tabular}{lll}
\hline Time & The territories of the Austro-Hungarian Empire, & Time \\
series & $\begin{array}{l}\text { integrated in the Romanian state after 1918 } \\
\text { (until 1940 for Northern Bukovina) }\end{array}$ & series \\
& &
\end{tabular}

The territories of the Russian Empire integrated in the Romanian state (1918-1940) and occupied by the Soviet Union (including north of Bukovina and Herța county)

1850- Varga, E.A., Erdély etnikai és felekeweti

1827, Статистическое описание Бессарабий,

1992 statistikája. Népszámlálási adatok 1850-1992

1831 Tipogr.I.M.Grinștein, Akkerman, 1899; Карта

között, Teleki Lászlo Alapitvány, Budapest, 1998.

1851 Mitteilungen an dem Gebiete der Statistik. Ubersiches Tafeln zur Statistk der Östen театра войны в Европе, 1828-1829 годов, $1 / 420000$, Sankt Petersburg, 1835 (facs.)

Monarchie, Wien, 1852

1859, Ladaniuc V, Țopa T., Nicu V., Localitățile

1875 Republicii Moldova, vol.I-XVI, Fundația

Draghiștea, Chișinău, 2006-2016; Poștarencu D.,

1869 Orts-Repertorium des Herzogtums Bukowina

(Auf Grundlage der Volkszählung der 31

Dez.1869), Czernowitz, 1872

1880 Special Orts-Repertorien der im

Österreichischen Reichsrathe, vol.XIII,

Bukowina, Wien 1885.

1890 Special Orts-Repertorien der im

Österreichischen Reichsrate, vol.XIII, Bukowina,

Wien 1894.

1900 Gemeindelexicon der im Reicshrate Vertretenen

Königreich und Lander, vol.XIII, Bukowina, Wien,

1907; E.Grigorovitza, Dicționarul geografic al

Bucovinei, București, 1908.

1910 Volkszählung vom 31. Dezember 1910, veröffentlicht

in: Geographischer Atlas zur Vaterlandskunde an

der österreichischen Mittelschulen. K. u. k. Hof-

Kartographische Anstalt G. Freytag \& Berndt, Wien

1911; Torouțiu, I.E., 1916, Poporația și clasele

sociale din Bucovina, București.

1930 Recensământul general al populației din 29.12.1930, vol II., ICS, București, 1941.

1941 Recensământul general al populației din 06.04.1941, ICS, București; Indicatorul localităților din România. Datele recensământului din aprilie 1941 și aug.-sept.1941, ICS, București, 1943, 1944,

1948 Golopenția, A., Populația P.R. la 25 ian.1948, ICS, 1949 Ladaniuc V, Țopa T., Nicu V., Localitățile București, 1948

1897 Первая всеобщая перепис 1897, III, Бессарабская губерния, Ц.С.К., Sankt Petersburg, 1905.

Republicii Moldova, vol.I-11, Fundația Draghiștea, Chișinău, 2006-2013.

1956 Recensământul populației din 21.02.1956, DCS, 1959 Всесоюзная перепись населения 1959 года; București, 1959-1960.

Ladaniuc V, Țopa T., Nicu V., Localitățile Republicii Moldova, vol.I-11, Fundația Draghiștea, Chișinău,2006-2013.

1966 Recensământul popu.lației și locuințelor din 15.03.1966, vol.I-IV, DCS, București, 1969.

1970 Всесоюзная перепись населения 1970 года; Ladaniuc V, Țopa T., Nicu V., Localitățile Republicii Moldova, vol.I-11, Fundația Draghiștea, Chișinău, 2006-2013.

1977 Recensământul populației și locuințelor din 1979 Всесоюзная перепись населения 1979 года. 05.01.1977, vol.I-IV, DCS, București, 1980-1981.

1992 Recensământul populației și locuințelor din 1989 Всесоюзная перепись населения 1989 года; 07.01.1992, vol.I-III, CNS, București, 1994. Popescu, I., Populația românească din regiunea Cernăuți la sfârșitul perioadei sovietice; http://database.ukrcensus.gov.ua

2002 Recensământul populației și locuințelor din 18.03.2002, baza de date Tempo-Online, INS, București.

2011 Recensământul populației și locuințelor din 20.10.2011, baza de date Tempo-Online, INS, București.
2001, Всеукраїнський перепис населення 2001 2004 www.ukrstat.gov.ua ; Rezultatele recensământului populației din 2004, Biroul Național de Statistică al R.Moldova www.statistica.md

2014 Всеукраїнський перепис населення 2001 www.ukrstat.gov.ua 


\section{Results and discussions}

Preliminarily, several cartographic materials prior to 1918 were analysed in order to capture the distribution of the main ethnic groups in the studied territories. Most of them reflected faithfully the spread of ethnic groups or contact / mixed areas. It is the case of Kiepert's Ethnographic Map (1876) which used the results of the modern censuses carried out in the Habsburg Empire (1851, 1861 and 1869) or in the United Principalities (1859-1860), as well as the official estimations in the Ottoman and Tsarist Empires (Figure 1). The integration of the areas predominantly inhabited by Romanians inside the borders traced after 1918 is remarkable, despite the cartographic manipulations during the peace negotiations, which staked on the integration of the population density into the distribution of the ethnic groups. The famous maps of Count Teleki, which have been preserved, reveal that the mountainous area was completely deprived of its population, in order to diminish the territorial importance of the Romanian presence.

From the perspective of the conceptual analysis presented in the introduction for the period preceding the events of the year 1918, some specific features of the evolution of the ethnic structure generated by the political context in the AustroHungarian or Tsarist empires can be noted (Lafferton, 2007; Floroaia, 2014). Similarly, there were significant changes after the integration into the Romanian Kingdom or, in particular, due to the effects of the second world conflagration.

In the territories that were part of the Austro-Hungarian Empire, beginning with the second half of the XIX ${ }^{\text {th }}$ century, the assimilation policy grew stronger, especially in the territories administered by Hungary, against the background of some national movements with an ethnic and territorial motivation, a context frequently cited in the literature in the field (Lafferton, 2017). The assimilation policy enforced a separation of the Magyar (with an ethnic meaning) and Hungarian (with a political meaning) terms. As such, beginning with 1880, the language was introduced as an element of self-definition at the census in order to favour the dominant ethnic group. As a result of this policy, the role of language in forging national identity increased among ethnic groups, primarily in the case of the Romanians in Transylvania. Some authors link this evolution to the argument of the Latin origin of the Romanian language, an origin considered to be "superior" (Baar and Ritivoi, 2006). In contrast, for the Hungarian population, the essential identity element was the status of shield of Christianity. The confession division of Romanians, Hungarians and Germans did not affect the forging of a strong national identity. The rise of religious pluralism deepened the social role of religion, removing internal confessional antagonisms (Floroaia, 2014). 


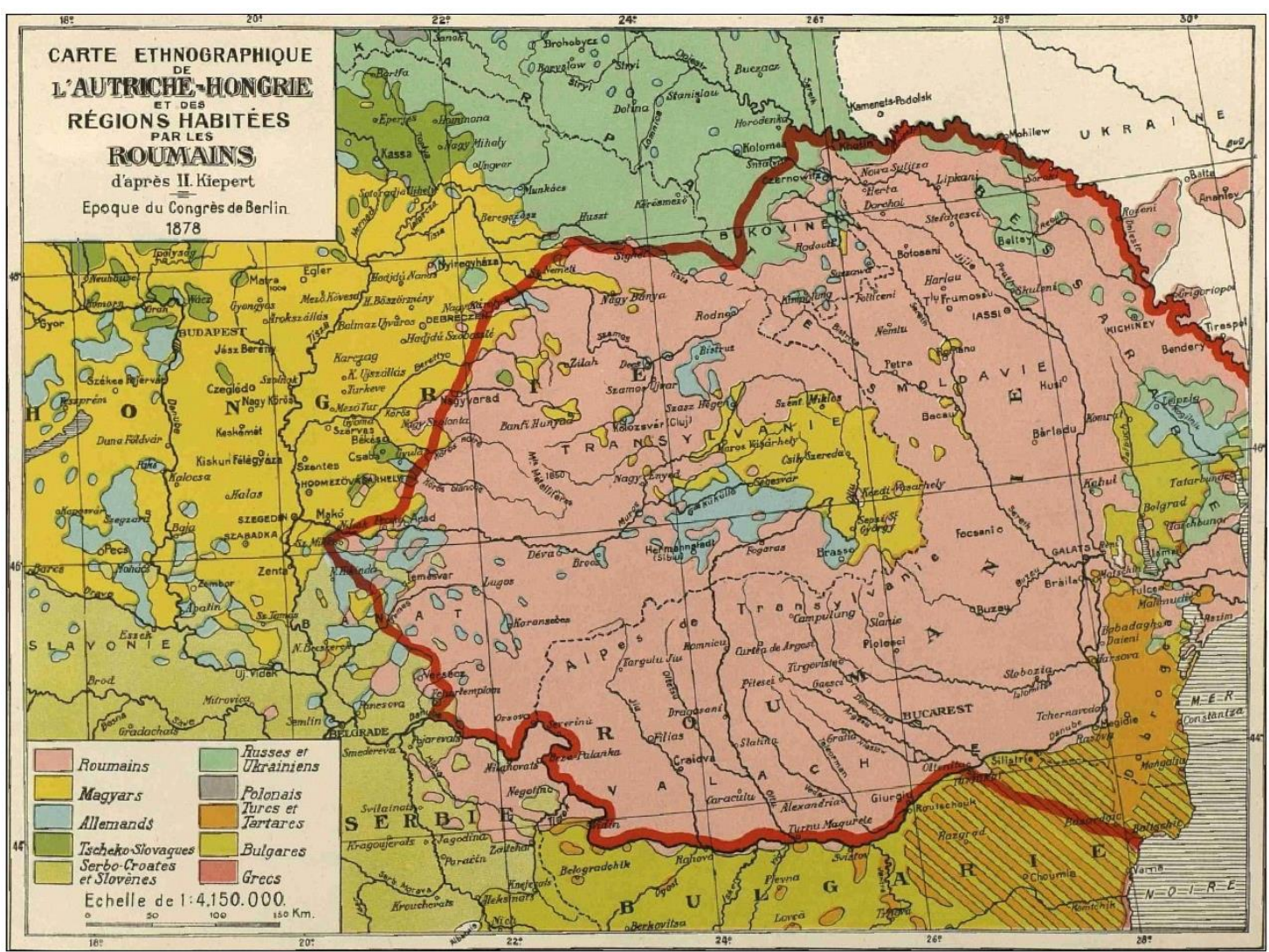

Figure 1. Kiepert's ethnographic map of 1876

After 1918, ethnic relationships in Transylvania, Banat, Crişana and Maramureş enforced, rather at the declarative level, a policy of "Romanianization", especially of important cities. Bowd and Clayton (2015) believed that those actions were grounded on the "new Romanian geopolitics", post-1918, imposed by the geometric vision of Emmanuel de Martonne (circle, set square and spine). The cited authors invoke a speech delivered by the mayor of Cluj in 1921 that said "We have to build Romanian Cluj, because this is a vertebra, part of the backbone of the Romanian state body."

The collision between Romanian and Hungarian identity constructions has thus become perpetual. Some authors, including Kulcsár and Bradatan (2007), consider that "the political obsession over Transylvania, both in Hungary and Romania, has historical roots in redefining the nation-state after 1990". After the integration in the European Union, the importance of the ethnical approach has decreased and there is hope for the redefinition of trans-ethnic Transylvanian identity. Minorities and their leaders oppose the political pressure in their country of origin, even if they come directly from governmental bodies. In the context of 
political pluralism, the presence of minorities also involves wider possibilities of electoral manipulation in all camps (Goodnow et al, 2014).

In the territories occupied by the Soviets in 1940, Bessarabia, northern Bukovina and Hertza Region, the situation differs significantly before and after 1918. In Bessarabia, the concentration of the native population in the countryside, partly marked by autarchy (especially in the areas mainly inhabited by yeomen) allowed the preservation of national identity in its "medieval", Moldovan form. By contrast, in Bukovina and the Land of Hertza, the triumph of the Romanian ethnic and linguistic identity anchored these territories even more strongly in the national socio-cultural circuit. Paradoxically, over time, while being exposed to processes of ethnic interassimilation, the Moldovan identity was stronger than the Romanian one, the latter failing to counteract the progressive Ruthenization wave, which from the Prut and the Ceremus quickly moved to Siret and Suceava rivers in the second part of the XIX $X^{\text {th }}$ century. In Bessarabia, the massive estrangement of some regions (especially the southern parts) was the result of the complete reshuffle of the ethnic picture following the evacuation of the Nogai Tatars and the allogeneic colonisations organized by the Tsarist regime. An exception was the extreme north, the Land of Chotyn, a former Turkish vilayet between 1711 and 1812, where the ancient ethnic contact between Moldovans and Ruthenians created an early ethnic limit, sufficiently clear and stable until today, with small fluctuations induced by the change of the political regime. The poor development of the urban system and its predominantly commercial character did not generate a strong assimilation pressure, the status of communication language being granted to Russian between 1812 and 1918.

During the Soviet period, although Russia strongly encouraged the movement of the Russians and Ukrainians in the Republic of Moldova, a process also continued during the tsarist period on other coordinates, the ethnic status-quo was preserved from a strictly territorial point of view (Jackson, 2003, p.86). Some authors bring forward a central policy of preserving the long-term stability of the complex ethnic mixture in the ex-Soviet space, in order to avoid unstable situations generating uncontrollable effects (Stone, Routledge, 2003, p. 290).

By de jure federally, the Soviet state was de facto unitary, the notion of territory becoming a component of a hierarchical system of structuring ethnic autonomy, thus generating an essential element for the national ideology, despite the creation of the "Soviet people" (Knippenberg and Dostal, 1992, p.631). This explains why, apart from a minimum autonomy, the Romanian population in the Ukrainian regions of Odessa, Chernovtsy and Transcarpathia survives precariously, unlike in the Republic of Moldova which, in fact, underwent the same Russification process during the Soviet period. At present, Russia does not have a well-defined role, limiting itself to a fluid position, oscillating between going on with its Soviet 
practices and an attitude of indifference, between the stimulation of anarchy and the hierarchization of groups (of ethnic or other origin), depending on the degree of fidelity, under the empire of a policy of "multiple hegemonies" (Gayoso, 2009).

\subsection{Dynamics of population by the ethnic structure}

The integration of the provinces that belonged to the Austro-Hungarian or Tsarist Empires after the events of 1918 meant, to a great extent, the integration of some very important minority groups that significantly changed the prospects of national cohesion in comparison to the situation in the Old Kingdom, where the Romanian population represented the vast majority, the Jewish communities in Moldavian towns or the Gypsies scattered throughout the whole territory being relatively integrated.

The ethnic structure of the joined provinces was complicated by the differentiated distribution of some communities, some of them predominantly urban (primarily Jews), others concentrated in rural areas (mostly Romanians but also Ukrainians in Bukovina or Bessarabia etc.).

In the provinces within the Carpathian arch, the evolution was in keeping with the great political events. The setting up of the dualist regime and the amplification of the Magyarization process led to a significant increase in the share of the Hungarians in the second half of the XIX ${ }^{\text {th }}$ century, adjusted by their integration into Greater Romania. Even so, in 1930, the percentage of this community was higher than the level recorded in 1850 and remained within these limits even in the post-war period, until the fall of the totalitarian regime. Only after 1990 the Hungarians' share significantly decreased from 22 to $18.4 \%$, against the background of their emigration, primarily towards neighbouring Hungary. In the period 1990-2011, 11.3\% of the definitive emigrants at the national level went to Hungary, well above the share of the Hungarian population, according to the National Institute of Statistics. The theory of an alleged "Romanianization" of these provinces in the post-1918 period cannot be supported (Gellért, Rosière, 1989). The increase in the Romanians' percentage, especially after 1956, was mainly due to the massive drop of the share of the German population and to the higher birth rates in many predominantly Romanian areas (Maramures, Oas, Bistrita-Nasaud etc.). Transylvania, Banat, Crisana and Maramures also stand out through a recent rise in the share of other communities, especially Gypsies (see Table 2).

In the case of Bukovina, the evolution of the ethnic structure was significantly different. After being for a long time administratively connected to Galicia and integrated into the human flows directed predominantly from it, it witnessed a complete disruption in the second part of the XIX ${ }^{\text {th }}$ century. At that point, the share of the Romanian population dropped dramatically, from a still relatively significant 
Table 2. Evolution of the ethnic structure of the population in Transylvania, Banat, Crișana and Maramureș

\begin{tabular}{lccccccc}
\hline Nationality & $\mathbf{1 8 5 0}$ & $\mathbf{1 8 8 0}$ & $\mathbf{1 9 1 0}$ & $\mathbf{1 9 3 0}$ & $\mathbf{1 9 5 6}$ & $\mathbf{1 9 9 2}$ & $\mathbf{2 0 1 1}$ \\
\hline Romanian & 58.4 & 56.7 & 53.7 & 57.7 & 64.8 & 69.2 & 75.4 \\
Hungarian & 22.8 & 24.6 & 29.6 & 24.4 & 24.6 & 22.0 & 18.4 \\
German & 12.0 & 12.0 & 10.4 & 9.8 & 6.1 & 4.8 & 0.5 \\
Other & 6.8 & 6.7 & 6.4 & 8.1 & 4.5 & 4.0 & 5.7 \\
\hline
\end{tabular}

Source: see Table 1.

majority in 1851 to only $1 / 3$ in 1910 , to the detriment of the Ukrainian element, closely related to the insidious ways of population recording (by language of communication), as well as to the assimilation of Romanians in areas with a Ukrainian majority (Kalusznizcki, quoted by Nistor, 1991, p.315). In the case of Greater Romania, this trend was reversed, the swap between the two major communities, the Romanian and Ukrainian ones, being primarily generated by the reconsideration of ethnicity but not of linguistic affiliation. This was primarily the case in the two Northern Bukovina counties, Chernivtsi and Storojineț, where in 1930 the share of declared Ukrainians was of $44.5 \%$ and $45.5 \%$, respectively, but the share of those enumerated by Ukraine as their native tongue rose up to $48.9 \%$ and $50.5 \%$, respectively. At the same time, Romanian-speaking people were less numerous than those who had embraced a Romanian ethnic identity. The splitting up of the province after 1940-1947 triggered a completely different evolution, with a massive reduction of the German, Polish, Jewish communities etc. Consequently, in the post-totalitarian period it found itself in a typically binational context, with a slight Romanian predominance, explainable by its predominantly rural character (not only in the north of the province), more traditional from a demographic perspective (see Table 3).

Table 3: Evolution of the ethnic structure of the population in Bukovina

\begin{tabular}{lccccccc}
\hline Nationality & 1851 & $\mathbf{1 8 8 0}$ & $\mathbf{1 9 1 0}$ & $\mathbf{1 9 3 0}$ & $\mathbf{1 9 5 6 / 1 9 5 9}$ & $\mathbf{1 9 8 9 / 1 9 9 2}$ & $\mathbf{2 0 0 1 / 2 0 0 2}$ \\
\hline Romanian/Moldovan & 47.7 & 33.5 & 34.3 & 40.8 & 45.5 & 49.4 & 48.8 \\
Ukrainian & 35.5 & 41.7 & 37.8 & 33.0 & 42.1 & 42.8 & 46.4 \\
Other & 16.7 & 24.8 & 27.9 & 26.2 & 12.4 & 7.8 & 4.8 \\
\hline
\end{tabular}

Source: see Table 1.

However, the evolution has been strongly differentiated, with a strong homogenization tendency in the south province (95.5\% Romanians in 2011), where the Ukrainian minority became insignificant, but also in the north, where, against the resistance of the Romanian population, a comfortable Ukrainian majority is recorded (77.8\% in 2001). Bringing forth the multi-ethnic character of Bukovina can still be a reality in the north of the province, but not in the southern region, which has aligned the pattern of the other Moldavian counties.

In Bessarabia, administered by the Tsarist Empire until 1918 and between 1940-1991 and sharing the same fate with northern Bukovina, being occupied by the 
Soviets, the evolution of the ethnic structure was even more complex, explainable by the diffuse population density of most of the territory, which imposed massive colonisations with populations of various origins. While several decades after the occupation in 1812, the Romanians (Moldovans) still had a comfortable majority, towards the end of the XIXth century the situation changed dramatically, reaching only $1 / 2$ of the population (see Table 4 ). For the year 1897, we did not make use of the primary data provided by most sources based on a census that recorded the language of communication, a criterion that led to favouring the Russian-Ukrainian population to the detriment of the native population, primarily. We relied on the results corrected by Butovici after more accurate information acquired in the field (1916), also later used by Berg (1923). We consider that, given the ethnic origin of these authors, we can give credit to their estimates rather than to the official information that attested only a share of $47.6 \%$ Moldovans. For the year 1930, in the case of the Russians and Ukrainians, the Romanian census provided contradictory information, apparently favouring the Russian ethnicity, especially in mixed areas (Bugeac, the Land of Chotyn).

Table 4. Evolution of the ethnic structure of the population in Bessarabia

\begin{tabular}{llllllll}
\hline Nationality & $\mathbf{1 8 2 7}$ & $\mathbf{1 8 9 7}$ & $\mathbf{1 9 3 0}$ & $\mathbf{1 9 5 9}$ & $\mathbf{1 9 8 9}$ & $\mathbf{2 0 0 1 / 2 0 0 4}$ & $\mathbf{2 0 1 4}$ \\
\hline Romanian/Moldovan & 65.2 & 51.5 & 55.9 & 54.4 & 57.9 & 64.0 & 67.0 \\
Ukrainian & 15.6 & 19.3 & 11.7 & 20.7 & 18.6 & 17.0 & 15.3 \\
Russian & 3.9 & 6.1 & 12.0 & 11.5 & 12.5 & 8.9 & 7.8 \\
Bulgarian & 3.4 & 5.5 & 5.8 & 5.6 & 4.6 & 4.6 & 4.5 \\
Gagauz & 2.4 & 3.2 & 3.5 & 4.2 & 3.7 & 4.0 & 4.1 \\
Other & 9.5 & 14.5 & 11.1 & 1.3 & 2.7 & 1.6 & 1.2 \\
\hline
\end{tabular}

Source: see Table 1.

In fact, the correctness of the mentioned authors' remarks is certified by the results of the 1930 Romanian census and by the post-war evolution, against the massive colonisations and progressive assimilation under the Soviet occupation. In 1989, the Moldovans' share was virtually higher than in 1930, which can be explained by the same context of rural predominance and Moldovan specific demographic traditionalism. From a strictly spatial point of view, except for urban centres, at least in the case of the Republic of Moldova, there were no essential changes, the distribution of the localities with a Romanian / Moldovan majority in 1970 being similar to that from 1930 (Ungureanu, 1997). The fact that the Republic of Moldova (which occupies $2 / 3$ of Bessarabia and owns $3 / 4$ of the population) obtained its independence generated a trend of continuous strengthening of the Moldovan (Romanian) element. Corroborating the 2014 census data with the older information on the areas belonging to Ukraine (2001), a value of $67 \%$ was obtained for this date, superior to the one in the first part of the analysed period. At the same time, after the spectacular increase of the Russian-Ukrainian population, in the Soviet period, after 1989 there was a gradual reduction, unlike in the case of the Bulgarian-Gagauz 
communities, which enjoyed a relatively constant evolution against the background of a dramatic decrease of other communities, which used to be more important in the past (the German community, even since 1940, the Jewish one, especially after 1989). In conclusion, a comparative analysis of the three distinct cases shows how important territorial ownership is. Transylvania, integrated in Romania, experienced a linear evolution of the share of the Romanian population, divided Bukovina registered divergent dynamics of the two ethnic components (Ukrainian and Romanian) and Bessarabia, especially within the territory that became independent after 1991, succeeded in reversing the unfavourable tendencies of the majority population. This is not the case of the regions attached to Ukraine (Lozovanu et al., 2018).

\subsection{The typology of the evolution of the ethnic structure at the territorial level}

This analysis revealed significant differences between the territories belonging to the Romanian state and those belonging to the U.S.S.R. The reference levels used were the current NUTS 3 administrative distribution for Romania and the administrative division by interwar counties for Bessarabia. The North of Bukovina was considered as an independent entity and the Land of Hertza, abusively occupied by the Soviets in 1940, was also taken into account separately.

The differences noticed lead to the conclusion that the political factor has an unequal capacity to change the ethnic structure, lower in Romania and much stronger in U.S.S.R., where massive population movements between the union republics were organized or stimulated.

However, the urbanization process, which was less represented before 1918, speeded up during the totalitarian period everywhere, bringing about significant changes in the structure of the urban population, closely related to the ethnic predominance of the rural population in the immediate vicinity, especially in Romania, but also to the policies of ethnic "favouritism" promoted in the Soviet Union. Thus, cities located in the predominantly Romanian regions of the Republic of Moldova or Ukraine experienced a massive Russification / slavization process (Reni, Tighina, Bălți and even Kishinev), while those located in ethnic contact areas limited the "access" of the Romanian / Moldovan population (Ismail, Chilia and especially Cernăuți). In Romania, on the contrary, despite the influx of Romanian population, including from the southern or eastern regions of the country, the cities in the regions predominantly inhabited by Hungarians preserved the ethnic profile of the neighbouring rural areas (Miercurea-Ciuc, Odorheiu Secuiesc or Sfântu Gheorghe, for example), while those in the ethnic contact areas preserved their mixed character (Târgu Mureş, Satu Mare and, to a smaller extent, Oradea or Zalău).

The special demographic vitality of the rural communities in Soviet-occupied areas diminished the impact of the massive change in the ethnic structure. From a 
purely statistical perspective, the presence of the native population is, at least apparently, strengthened in the Republic of Moldova after its independence. The situation is much more shaded in the territories integrated in the Ukrainian state, where the evolutions are sometimes dramatic, following a scenario of assimilation successfully applied even since the interwar period in Transdniestria. Even on the territory of Romania, the demographic vitality of the rural population sometimes kept the status-quo prior to 1918 in favour of the Hungarian minority (Hungarianspeaking), in the case of the counties of Szeklerland or Sălaj. The changes were spectacular especially in towns, and particularly in cities, extremely attractive in the Romanian national context.

In the territories that belonged to the Austro-Hungarian Empire until 1918 and that have been integrated into the Romanian state ever since, the typological classification performed separately for the rural space and small towns on the one hand, for the important cities on the other, certifies the previously mentioned remarks. The divergent evolution of the two categories of localities before 1918 is significant: while in the predominantly rural areas the share of the two major communities, Romanian and Hungarian, was relatively constant, the important cities often recorded a very spectacular growth of the Hungarians, especially in those places where their number was smaller at the beginning of the period (in the cities of southern Transylvania). Arad and Timișoara represented a special case, the massive presence of the German population hindering this influx of Hungarian population (Figure 2). Important cities with a prevailing Hungarian population experienced a steady evolution. This process of "Magyarization" of important cities could be considered artificial, taking into account the fact that it also happened in rural areas with a net Romanian majority as well (Alba, Hunedoara, etc.). In the process of consolidating the Hungarian nation, however, it is fully justified.

The integration of these territories into the Romanian state produced a relative disruption of the ethnic structure, visible in stopping the Magyarization process, especially in cities but also in rural areas with a mixed population (Bihor, Sălaj, Satu Mare, Mureş), including by reconsidering one's ethnic affiliation, especially among the Jewish minority which, in the last decades before 1918, was massively assimilated to the Hungarians (Manuilă, 1938). This happened also because some Austro-Hungarian censuses recorded the language of communication and not the mother tongue, ignoring ethnic self-identification (Austrian census, 1910). The occupation of north-western Transylvania between 1940-1944 led to a rapid, episodic change, especially in important cities, taking the shape of an "ethnic cleansing" generated by the massive escape of the Romanian population. All these changes can be considered as having a nationalist origin, integrated into the ideologies of the "century of nationalities". 
(a) Cartographic representation

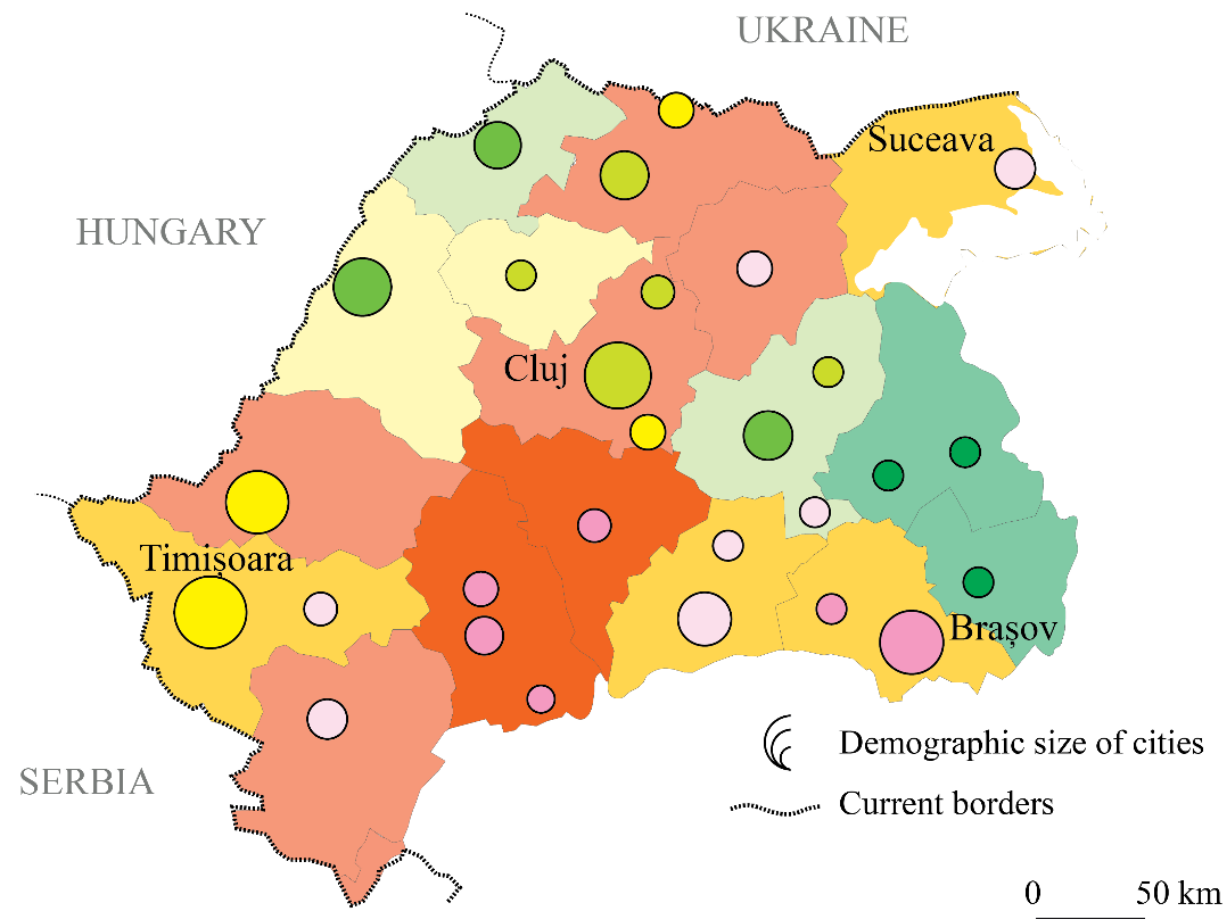

(b) The typology of rural space and small towns
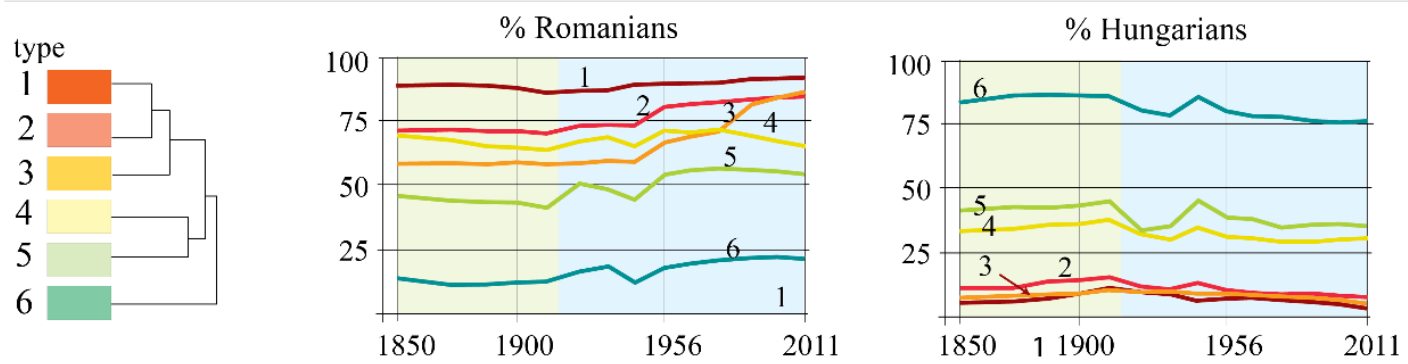

(c) the typology of main cities
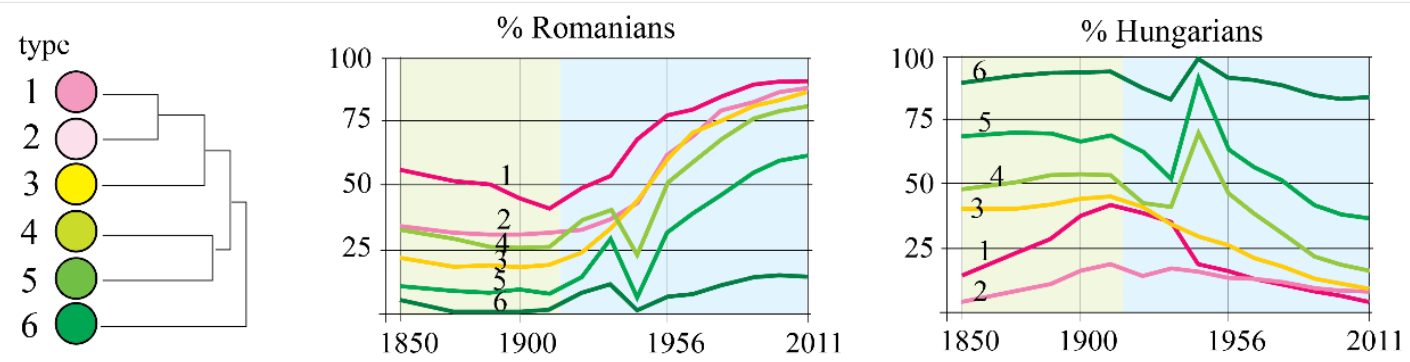

Figure 2. The typology of the evolution of the ethnic structure in the territories that belonged to the Austro-Hungarian Empire until 1918 
In the post-war period, the process of ethnic restructuring that was taking place before 1940 was resumed, eventually leading to a massive increase in the share of the Romanian population. This happened initially in the territories with a net predominance of rural areas, then in those with a high proportion of the German population, partially repatriated after 1947 or affected by a declining demographic vitality. The share of the Hungarian population remained close to the values at the beginning of the study period in rural areas. In cities, even though their share generally decreased, it continued to be significant in areas with an important Hungarian presence (Szeklerland, Northwest or even Cluj). The fact that the dynamics of the share of Hungarians in the cities in the southwest of the study area was quite divergent to that in the northwest is mainly due to its poor presence in the neighbouring rural areas and, subsidiarily, to the migration flows from other regions of Romania, which compensated for the departure of the German communities or the chronic denatalism of the Romanian population (in Banat and the south of Crişana, for example). This confirms the preliminary conclusions above, which emphasize the irrelevance of the opinions in favour of a "Romanianization" process. The preservation of the initial ethnic status-quo in mixed or predominantly Hungarian areas proves the solidity of the identity feeling, a strong argument in this respect. This argument can be reinforced by the fact that in some situations (Bihor, Sălaj) recent tendencies are more favourable to the Hungarian element, especially in rural areas, including against the background of the linguistic assimilation of some Roma communities, known for their prolificacy.

In the territories occupied by the Soviet Union in 1940, the typology of the evolution of the ethnic structure reveals completely opposite tendencies. They confirm the initial assumptions, their breaking off from the Romanian ethnic territory generating processes of ethnic marginalization, cleansing or (preferential) favouring. This latter process was visible in the staff recruitment policies of some companies (almost exclusively from Russia) set up in Bessarabia. Even the attempt to build a distinct ethnic-territorial identity, subordinated to the "Moldovan" current, with roots dating back to the Tsarist period, could not block the manifestation of these processes in the very special context of the ex-Soviet space, marked by insidious ethnolinguistic assimilation policies (Muntele and Ungureanu, 2017, p.281). Even more so in the territories integrated into the Ukrainian territory, these processes could not be hindered by anything, even in those areas where the ethnic mosaic seemed difficult to restructure, as it is the case with Bugeac.

The resulting typology reveals the presence of a gradient of the intensity of the mentioned processes, from the central core of Bessarabia (Orhei-Lăpuşna), more densely populated, with a relief limiting the possibilities of systematic colonization, to the northern and southern peripheries. The particular case of northern Bukovina largely approaches the evolution of the neighbouring land of Hotin and Herța, 
(a) Cartographic representation

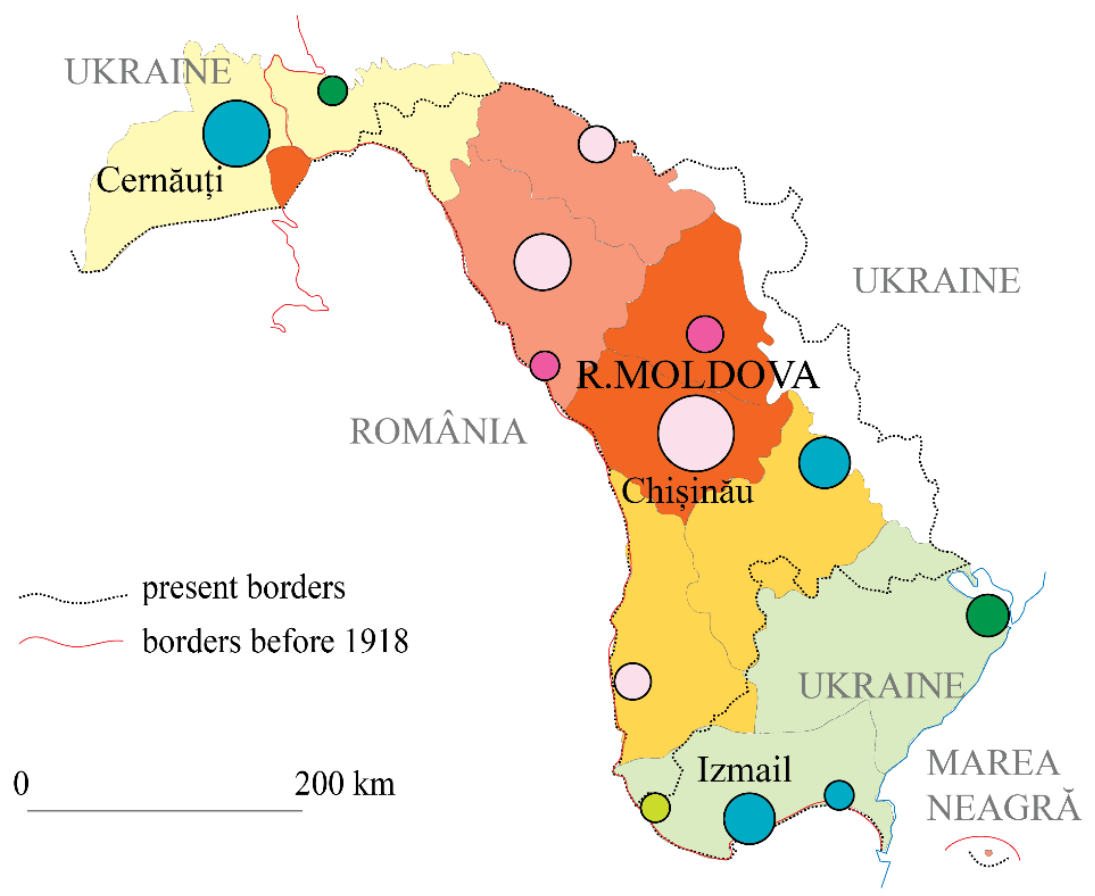

(b) The typology of rural space and small towns
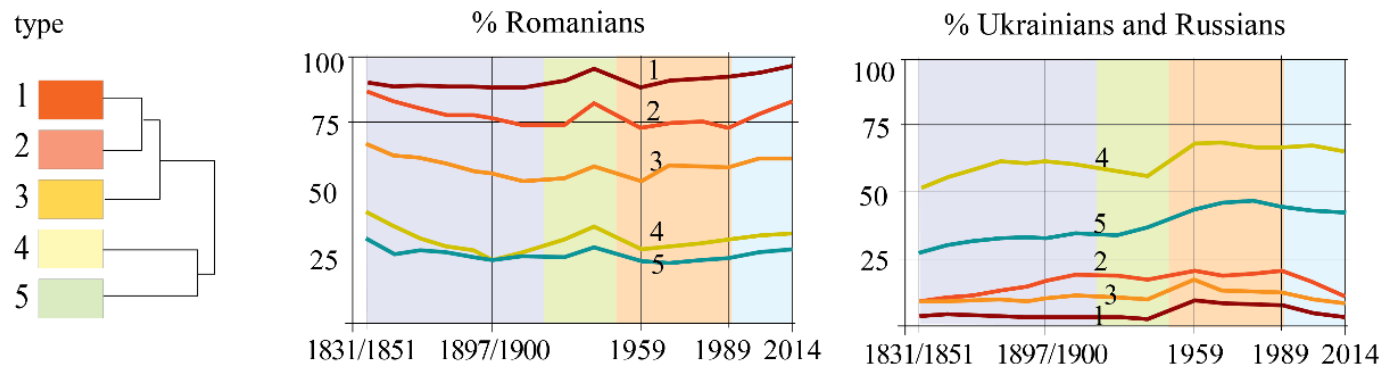

(c) The typology of main cities
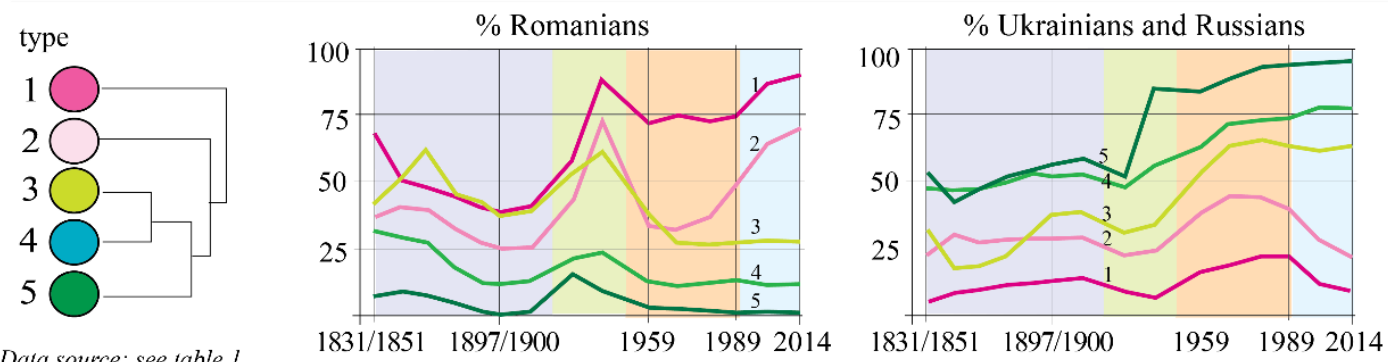

Data source: see table 1 .

Figure 3. The typology of the evolution of the ethnic structure in the territories occupied by the Soviet Union in 1940 
experienced similar dynamics to the above mentioned the central core. The intensity of the process of ethnic complexification before 1918 was the highest in the steppe regions of south-eastern Bessarabia; however, although the Romanian population recorded in almost all cases a significant reduction, it was not necessarily due to the advance of the Russian population, but primarily to the systematic colonization of important German, Bulgarian and Gagauz communities or, in the case of the northern part of the region, to the spectacular rise in the number of Jewish population. It can be stated that this context represented an obstacle for the possibilities of Russification of the native population that would have taken place on another scale if these colonisations had been exclusively targeted at the RussianUkrainian populations.

By contrast, in urban centres, insufficiently consolidated (with the exception of Cernăuți and Chișinău), the Romanian population recorded regressive tendencies, without exception, some of them becoming almost completely "alien" to the Romanian element (Hotin, Cetatea Albă), although it was significantly present within the rural area of Romanian population influence (Figure 3). For this reason, the rural areas neighbouring these cities experienced more frequent situations of decrease in the Romanian communities, until they completely disappeared.

A similar "de-Romanianization" process took place in Chernăuți, Izmail, Chilia or Tighina, on a smaller scale before 1918, a process partly disrupted by the integration into the Kingdom of Romania between 1918-1940. Even Chișinău or other middle-sized towns in Bessarabia experienced a massive reduction of the Romanian presence, but this was not due to an exaggerated increase of the Russian-Ukrainian presence. Unlike the north-west of Romania, previously analysed, the vector of the change suffered alterations before 1918, the Jews being the most dynamic ethnic group in the urban centres, in the post-war period their place being taken by Ukrainians and Russians. We can consider that this change was also the expression of a compensation dictated by the reduction of the Jewish population's weight in cities, but this would normally have had to be the result of a massive increase in the share of the native population, as it happened at the west of the Prut, in a similar context. The imperialist and internationalist character of the ethnic policies of the Tsarist Empire and then of the Soviet Union explain these evolutions.

Despite the whole policy of denationalization, the ability to preserve the ethnic status-quo is remarkable. While during the Tsarist period the vector of shrinking the Romanian ethnic area was represented by allogeneic settlements, during the Soviet period the changes occurred mainly in the urban centres, even in the territories integrated in Ukraine. The main explanation lies in the remarkable vitality of the indigenous rural population, in the Republic of Moldova the share of "Moldovans" growing by $12 \%$ in villages in the post-war period, while at the national level it decreased by 1.5\% (Matei et al, 2017, p.38). However, this rurality of the native 
population hides a profound vulnerability in the context of the contemporary society, in which the city gradually shapes and infuses the proximate rural area, including from a cultural perspective. Without strong urban communities, disposing of the cultural, social and civic infrastructure necessary to preserve their identity, even these resilient rural communities can alter their ethnic substance by cultural or even linguistic assimilation. Fortunately, for the territory of the Republic of Moldova, after 1990 we have witnessed a process of ethnic (re) integration of urban centres with the rural majority, very visible in the case of Chișinău (76\% Moldovans / Romanians in 2014 compared to only $48 \%$ in 1989 within the city itself). On the contrary, in the territories belonging to Ukraine, the number of the Romanian population decreased continuously (from $27 \%$ in 1930 to $7.6 \%$ in 1989 and 6\% in 2001 in the case of the city of Cernăuți, for example).

\section{Conclusions}

The results of the statistical analysis as they have been presented, beyond the unpredictable objectives of the official records, certify the initial assumptions, integrated into the current trends of relativization of ethnicity, which is no longer conceived in a static but dynamic meaning, in close connection to the more or less sustainable territorial-political constructions. It thus becomes part of the formation of modern nations, a process which increasingly transgresses ethnic identity, becoming a civic notion. While in most Western European states this process can be considered concluded, notions such as citizenship, nation / nationality almost merging, in the east of the continent it still represents an ongoing process. In both analysed geographic areas, the north-west of Romania and the territories ceded by the Romanian state to the Soviet Union in 1940, the process of national consolidation is in an intermediate phase, in which the importance of the matter of ethnic minorities and of identity issues remains topical.

The importance of the political-state affiliation has been strongly emphasized. Thus, living outside the Romanian national territory after 1940, the Romanians / Moldovans from the ex-Soviet territories did not have the same chances of manifestation as those from Transylvania, Banat, Crişana or Maramureş. The migratory exchanges with the other Romanian regions allowed the initiation of the osmosis that strengthened social bonds or compensated for the gaps left by the mass departure of minority groups. The resistance opposed by the Hungarian minority, prior to 1918, part and parcel of Hungary's national project, although still providing enough levers for preserving cultural identity, gradually narrowed to those areas with a net ethnic predominance. By contrast, in Bessarabia or northern Bukovina, the integration into the vast territorial structure of the Soviet Union distorted national identity, generating after 1989, not only in the Republic of Moldova, an identity crisis 
still incompletely solved out (Cazacu and Trifon, 2017). This crisis has the effect of jeopardizing the formation of a national consciousness in accordance with the truth. Taking the risk of being completely immersed in a confused Russian mass in the Soviet era and lacking the necessary institutions for cultural survival, the native communities bear, after nearly three decades since the fall of the Soviet Union, the evil effects of the alteration of their ethnic and linguistic identity. The support naturally expected from the Romanian state was rather vague and symbolic in the absence of a proper understanding of the concrete situation. The massive decline of the population of Russian origin, secondarily of Ukrainian origin too, limited mainly to urban centres, did not lead to the decrease of the assimilationist pressure in the territories belonging to the Ukrainian state and did not allow the full recovery of the ethno-linguistic primacy in the Republic of Moldova.

The consolidation of the Romanian presence in the main urban centres within the Carpathian arch is undoubtedly the vector of the durable anchorage of the adjacent territories in the Romanian national construction. The importance of integrating "estranged" territories into national states in order to preserve and assert ethnic identity is thus certified. Otherwise, as exemplified especially by northern Bukovina or southern Bessarabia, ethnic favouritism can exert a strong assimilation pressure, especially in urban centres. The case of the Republic of Moldova is much more sensitive, given its geopolitical difficulties of asserting itself as an independent state. Theoretically, the affirmation of a Moldovan nation has nothing unnatural in itself, the state being officially recognized internationally. The perpetuation of the identity crisis prevents its forging and favours centrifugal trends, even under the current conditions of the decrease of the share of minority communities.

The validation of the two hypotheses must be taken in a general sense, the analysis being performed at regional level. In a strictly local context, they can be denied or confirmed depending on a complex of political, cultural or social factors. Last but not least, the spatial factor intervenes significantly. Concrete situations such as isolation or proximity to the borders of Romania and Hungary, respectively, can distort the observed trends.

\section{Disclosure statement}

No potential conflict of interest was reported by the authors.

\section{ORCID}

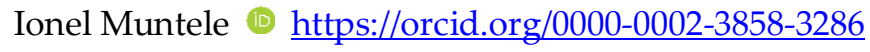




\section{References}

Baar, M., Ritivoi, A.D. (2006). The Transylvanian Babel: Negotiating national identity through language in a disputed territory, Language and Communications, 26, p.203-217.

Берг, А.С. (1923). Население Бессарабии. Этнографический состав и численность. Пг., СС. 640.

Blanton, R.E. (2015). Theories of ethnicity and the dynamics of ethnic change in multi-ethnic societies, PNAS, 112 (30), p.9176-9181.

Bowd, G., Clayton, D. (2015). Emmanuel de Martonne and the wartime defence of Greater Romania: circle, set square and spine, Journal of Historical Geography, 47, p.50-63.

Brubaker, R., Fleischmidt, M., Fox, J., Grancea, L. (2008). Nationalist Politics and Everyday Ethnicity in a Transylvanian Town, Princeton.

Burgess, R., Jedwab, R., Miguel, E., Morjaria, A., Padro i Miquel, G. (2011). Ethnic Favoritism, Preliminary Draft, $\underline{\text { https://www.dartmouth.edu/ neudc2012/docs/paper 230.pdf. }}$.

Бутович, В. Н. (1916). Материаль для этнографической карты Бессарабской губернии. Киев.

Cazacu, M, Trifon, N. (2017). Republica Moldova. Un stat în căutarea națiunii, Cartier, București.

Churchill, S.A., Smith, R. (2017). Ethnic Diversity and Poverty, World Development, 95, p.285302.

De Luca, G., Hodlerb, R., Raschky, P., Valsecchid, M. (2018). Ethnic favoritism: An axiom of politics?, Journal of Development Economics, 132, p.115-129.

Dostal, P.F., Knippenberg, H (1992). Russification of soviet nationalities: the importance of territorial autonomy, History of European Ideas, vol. 15, no 4-6, p.631-638, Pergamon Press Ltd.

Floroaia, M., (2014). Confessional Pluralism in Habsburg Transylvania, Social and Behavioural Sciences, 149, p.359-364.

Gayoso, C. (2009). Russian hegemonies: historical snapshots, regional security and changing for Russia's role in the post-Soviet region, Communist and Post-Communist Studies, 42, p.233-252.

Gellért, G., Rosière, S. (1989). L'agitation nationaliste en Moldavie, Hérodote, no. 54-55, Les marches de la Russie, p.139-148, La Découverte, Paris.

Gödri, I. (2004). A Special Case of International Migration: Ethnic Hungarians Migrating from Transylvania to Hungary, Yearbook of Population Research in Finland, 40 (2004), p.4572.

Goodnow, R., Moser, R., Smith, T. (2014). Ethnicity and electoral manipulation in Russia, Electoral Studies, 36, p.15-27.

Jackson, N. (2003). Russian Foreign Policy and the CIS: Theories, Debates and Actions, Routledge, London.

Jones, D. (2018). Kin Selection and Ethnic Group Selection, Evolution and Human Behaviour, vol. 39, no 1, p.9-18.

Kiepert, H. (1876). Carte ethnographique de l'Autriche-Hongrie et des régions habitées par les Roumains, https://en.wikipedia.org/wiki/File:Ethnological map by Kiepert 1876.jpg.

Kulcsár, J.L., Brădățan, C. (2007). Politics without frontiers. The impact of Hungarian domestic politics on the minority question in Romania, Communist and Post-Communist Studies, 40, p.301-314. 
Lafferton, E. (2007). The Magyar moustache: the faces of Hungarian state formation (18671918), Studies in History and Philosophy of Biological and Biomedical Sciences, 38, p.706732.

Lozovanu, D., Muntele, I., Sârbu, C.-C. (2018). Structura etnică a populației în sudul Basarabiei: permanențe și schimbări la 100 de ani de la Marea Unire, Muntele, I., Ungureanu, A., Rusu, C., Spațiul românesc la 100 de ani de la Marea Unire, Editura Universității "Al.I.Cuza" Iași.

Manuilă, S. (1938). Aspects démographiques de la Transilvanie, Editura Inst. Central de Statistică, București.

Matei, C., Hachi, M., Sainsus, V. (2017). Formarea populaţiei Republicii Moldova, ASEM, Chișinău.

Muntele, I., Ungureanu A. (2017). Geografia populației, Sedcom Libris, Iași.

Nistor, I. (1991). Istoria Bucovinei, Humanitas, București.

Stone, J., Rutledge, D. (2003). Race and Ethnicity. Comparative and Theoretical Approaches. Blackwell, Malden/Oxford.

Thum, G. (2007). Ethnic Cleansing in Eastern Europen after 1945, Contemporary European History, 19 (1), p.75-81.

Ungureanu, A. (1997). Aspects géographiques de l'évolution de la structure ethnique de la population de la République de Moldavie dans les années 1930-1970, Analele UAIC, section 2b, Geografie vol. 42-43, p.175-189.

Wackermann, G. (2008). Géographie des civilisations, Ellipses, Paris. 